\title{
Editorial of dossier "Admissibility of Evidence in Criminal Process. Between the Establishment of the Truth, Human Rights and the Efficiency of Proceedings"1
}

Editorial do dossie "Admissibilidade da prova no processo penal: entre a busca pela verdade, os direitos humanos

e a eficiência do procedimento"

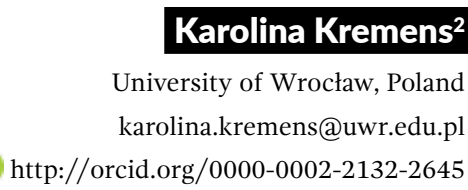

Wojciech Jasiński ${ }^{3}$

University of Wrocław, Poland wojciech.jasinski@uwr.edu.pl

http://orcid.org/0000-0002-7427-1474

AвSTRACT: The rules on the admissibility of evidence secure accurate fact-finding as a prerequisite for the correct application of substantive criminal law and proper operation of the criminal justice system in

1 This publication has been developed as part of the project Admissibility of Evidence in Criminal Proceedings. Between Truth Seeking, Fairness and Effectiveness of Proceedings (Registration No. 2017/27/B/HS5/00854) financed by the National Science Centre, Poland.

2 PhD in Law from the University of Wrocław (Poland) and LL.M. from the University of Ottawa (Canada). Assistant Professor at the Department of Criminal Procedure at the Faculty of Law, Administration and Economics (University of Wrocław, Poland).

3 Habilitation in Law and PhD in Law from the University of Wrocław (Poland). Assistant Professor at the Department of Criminal Procedure at the Faculty of Law, Administration and Economics (University of Wrocław, Poland). 
society. But the search for the truth must be limited in order to take into account other important values, among which human rights hold a central place. The quest for a fair balance between the effective fight against crime and respect for individual rights constantly remains in the center of heated discussion. However, there are two other factors that strongly influence the evidentiary rules, creating an environment where finding the truth becomes more complicated than ever before. The popularity of the disposition of cases out of trial and the impact of technology and science, both interrelated and focused on the efficiency of the criminal justice system, paradoxically make the quest for the truth easier and faster, but also more prone to errors. Moreover, the new technologies allowing evidence gathering have become a vital threat to the right to privacy. Finding solutions to these challenges necessitates dialogue including various stakeholders and free of the penal populism that has recently dominated the legal discourse.

KeYwords: admissibility of evidence; rights of individual; plea-bargaining; digital evidence; illegally obtained evidence.

Resumo: As regras sobre admissibilidade de provas garantem a verificação exata dos fatos como uma condição para a aplicação correta do direito penal material e o funcionamento adequado do sistema de justiça criminal na sociedade. Mas a busca pela verdade deve ser limitada para ponderar outros valores importantes, entre os quais os direitos humanos têm importância central. A meta de equilíbrio justo entre a persecução efetiva do crime e o respeito aos direitos individuais permanece constantemente no centro de acaloradas discussões. No entanto, existem dois outros fatores que influenciam fortemente as regras probatórias, gerando um cenário onde encontrar a verdade torna-se mais complicado do que nunca. A generalização da resolução de casos sem processo (barganha penal) e o impacto de tecnologia e ciência, ambas inter-relacionadas e dirigidas à eficiência do sistema de justiça criminal, paradoxalmente tornam a busca pela verdade mais fácil e rápida, mas também mais sujeita a erros. Além disso, as novas tecnologias que permitem a coleta de provas tornaram-se uma ameaça determinante ao direito à privacidade. Encontrar soluções para esses desafios exige um diálogo que inclua as várias partes interessadas e livre do populismo penal que recentemente dominou o debate jurídico.

PalaVRas-chave: admissibilidade da prova; direitos individuais; barganha penal; prova digital; ilicitude probatória. 
"When Jesus of Nazareth, in the hearing before the Roman prefect, confessed to being a king, he said: 'I was born and am come into this world to bear witness to the truth'. At which Pilate asked 'What is truth?' The sceptical Roman obviously expected no answer to this question, nor did Our Lord give any. For to be witness to the truth was not the essence of his mission as a Messianic king. He was born to bear witness to justice, that justice which he wished to realise in the Kingdom of God. And for this justice he died on the cross.

So behind Pilate's question: What is truth? there rises from the blood of the crucified another and still weightier question, the eternal question of mankind: What is justice?"

Hans Kelsen, What is Justice?, Berkeley 1957, p. 1.

\section{THE TRUTH-SEEKING IN CRIMINAL PROCESS - BETWEEN THE DIVERGENCE AND THE CONVERGENCE OF THE SYSTEMS}

Adequate fact-finding is frequently presented as the most fundamental principle of criminal process ${ }^{4}$. Yet, despite the perception of the truth as the essential element of the successful operation of the criminal justice system, lawyers keep posing the question whether the truth is the most important value of all that comes in play in criminal process and whether the truth should be sought by all possible means and at all costs. As observed by scholars in a consciously ridiculed way, commenting on what the US criminal trial has become in the eyes of the public after the OJ Simpson verdict, "we must bag, once and for all, the

4 See for example WEIGEND, Thomas. Should We Search for the Truth, and Who Should Do it? North Carolina Journal of International Law and Commercial Regulation, vol. XXXVI, pp. 389-415, 2011, p. 389 (in relation to Germany and France); WALTOŚ Stanisław; HOFMAŃSKI Piotr. Proces karny. Warszawa: Wolters Kluwer, 2016, p. 220 (in relation to Poland); BORGERS Matthias J.; STEVENS Lonneke. The Netherlands: Statutory Balancing and a Choice of Remedies. In: THAMAN Stephen C. (ed.) Exclusionary Rules in Comparative Law. Springer: Dordrecht-Heidelberg-New York-London, 2013, p. 183 (in relation to the Netherlands), BACHMAIER WINTER Lorena. Spain: The Constitutional Court's Move from Categorical Exclusion to Limited Balancing. In: THAMAN Stephen C. (ed.), op.cit., p. 211 (in relation to Spain). 
outmoded notion that a trial is a somber "search for truth." "' And even if this is just an exaggeration, we should be searching for an answer to the question of whether the truth does lie in the center of criminal process and, if so, what are the limits of fact-finding and what other values should be considered under certain circumstances as more important than the pure and ultimate truth?

The view that establishing the truth is the main principle of criminal process is well grounded in the civil law countries. The common law jurisdictions, however, are frequently perceived as placing either consensus or fair contest between the parties above the truth. Nonetheless, accurate fact-finding is also a cornerstone of the criminal justice system in common law tradition. That is confirmed by the law ${ }^{6}$, case $\mathrm{law}^{7}$ as well as by the legal scholarship ${ }^{8}$. The differences between the adopted models of criminal process in the two main legal families are a fact, but should be understood as a consequence of promoting alternative methods of searching and establishing facts of the case, rather than an expression of a distinct goal the criminal justice system should serve 9 . From that perspective the role of the parties in adversarial disputes and the scope

5 BRADLEY Craig M.; HOFFMANN Joseph L. Public Perception, Justice and the "Search for the Truth" in Criminal Cases. Southern California Law Review, vol. 69, pp. 1267-1302, 1996, p. 1268.

6 See Rule 102 of US Federal Rules of Evidence, which provides that rules of evidence are designed to ascertain the truth and secure a just determination. English Criminal Procedure Rules state that the ultimate goal of criminal proceedings (Rule 1.1.) is acquitting the innocent and convicting the guilty. Although the accurate fact-finding is not mentioned, it is obvious that it is necessary to apply ius puniendi correctly.

7 See examples from England and Wales, Canada and USA in: HO Hock Lai. A Philosophy of Evidence Law. Justice in the Search for Truth, Oxford: Oxford University Press, 2010, p. 52.

8 See: ROBERTS Paul; ZUCKERMAN Adrian, Criminal Evidence, Oxford: Oxford University Press, 2010, p. 19.

9 SPENCER John R. Evidence. In: DELMAS-MARTY Mireille; SPENCER John R. European Criminal Procedures, Cambridge: Cambridge University Press, 2002, pp. 636-637, WEIGEND Thomas. Should We Search for the Truth, and Who Should Do it?, op.cit., p. 414, VANDERMEERSCH Damien, Droit continental vs. droit anglo-américain: quells enseignements pour le droit belge de la procédure pénale, Revue de Droit Penal et de Criminologie, 2001, pp. 467-531, p. 513, ASHWORTH Andrew; REDMAYNE Mike. The Criminal Process. Oxford: 
of a judge's inquisitorial powers are tools of securing the most efficient and accurate fact-finding. As a result, the central role of the truth in criminal process, regardless of the legal family to which a legal system belongs, should not be questioned.

The pursuit of the truth in the criminal context is quite formalized. A variety of provisions refer to gathering, preserving, processing and evaluating relevant evidence. Among them the rules regarding admissibility of evidence are uniquely important. They serve a gatekeeping function and as a result may have an adverse influence on establishing the truth. Not surprisingly, the rules on the admissibility of evidence differ between the common law and Continental system, which will be discussed in this volume by Hanna Kuczyńska ${ }^{10}$. While the common law system opts for excluding some relevant evidence based on technical rules before it is heard in the courtroom, preventing the trier of fact from acknowledging the inadmissible evidence, the Continental model allows much more to be presented during trial and aims at evaluating the evidence post factum ${ }^{11}$. This distinction is ordinarily explained by the influence that laymen jurors have on the evidentiary rules in the common law system which is lacking in the Continental model. No doubt that in such a legal regime the more precise and harsher rules on the admissibility of evidence had to be developed ${ }^{12}$.

This leads to the identification of the origins of the evidentiary rules, which are as old as ancient criminal trials. Even though the evidence law has for a long time been in a position of a single unified subject in a common law system, while not as much in the Continental one, the evidentiary rules are not foreign to the latter either. Interestingly, it has

Oxford University Press, 2010, p. 23, KREMENS Karolina. Dowody osobowe w międzynarodowym postępowaniu karnym. Toruń: TNOiK, 2010, p. 60.

10 KUCZYŃSKA Hanna. Mechanisms of elimination of undesired evidence from criminal trial.

11 RYAN Andrea. Towards a System of European Criminal Justice. The Problem of Admissibility of Evidence, New York: Routledge 2014, p. 241.

12 See the classic discussion on the origins of evidentiary rules in connection to jury trials in common law system by DAMAŠKA Mirjan. The jury and the law of evidence: real and imagined interconnections. Law, Probability and Risk, vol. 5, issue 3-4, pp. 255-265, 2006. 
been argued that the reason why the contemporary rules on admissibility of evidence in the Continental criminal process embrace "free proof" is "an emphatic rejection of formalistic Roman-canon classification of evidence types and mechanistic qualifications of probative value"13. Illustrating that, Jerzy Skorupka takes us in this volume for a journey throughout the rules on admissibility of evidence of the Roman Empire, Ancient Greece and Teutonic tribes ${ }^{14}$. This analysis shows that the formal rules on evidence have also developed in the inquisitorial model and only incidental historical events have detached Continental Europe from the original inflexibility of rigid normative evidentiary rules.

It seems however that the era of differences is coming to an end. The evidence law currently faces unprecedented convergence. Although the criminal procedure in no way can be described as unified, similar tendencies in distinct countries can be observed, such as the growth of penal populism that results in retreat from some fundamental values ${ }^{15}$. Major changes can also be observed in the context of the European Union, which works hard on adopting common rules in criminal matters among EU members. With such tools as principles of mutual trust and recognition in criminal matters ${ }^{16}$, the European Arrest Warrant and the European Investigation Order ${ }^{17}$, common evidentiary standards are fast approaching. One example of such emergence of EU law relating

13 JACKSON John; ROBERTS Paul. Beyond Common Law Evidence: Reimagining and Reinvigorating, Evidence Law as Forensic Science. In: BROWN Darryl K., TURNER Jenia J.; WEISSER Bettina (eds.). The Oxford Handbook of Criminal Process, Oxford: Oxford University Press, 2019, p. 788.

SKORUPKA Jerzy. The rule of admissibility of evidence in the criminal process of continental Europe.

HODGSON Jacqueline S. The Metamorphosis of Criminal Justice. A Comparative Account, Oxford: Oxford University Press, 2020, p. 343.

See broadly on mutual recognition in MITSILEGAS Valsamis. EU Criminal Law. Oxford: Oxford and Portland: Hart Publishing, 2009, pp. 115-127. See specifically on mutual admissibility of evidence in the context of telephone tapping and house search in KUSAK Martyna, Mutual admissibility of evidence in criminal matters in the EU. A study of telephone tapping and house search, Antwerp: Maklu, 2016.

17 Directive 2014/41/EU of the European Parliament and of the Council of 3 April 2014 regarding the European Investigation Order in criminal matters [2004] OJ L130/1 1.5.2014 
to the collection of location data will be discussed in this volume by Dominika Czerniak ${ }^{18}$. But even outside of this peculiar European legal regime, a tendency to reimagine traditional evidentiary processes can also be identified through the proliferation of international criminal courts and tribunals. The direction in which the international criminal justice system developed in that regard is analyzed in this volume by Bartłomiej Krzan ${ }^{19}$. Whether the international criminal law may be named sui generis or is just an amalgam of two traditionally identified systems of criminal process may still be disputed ${ }^{20}$. Yet, it is certain that it adds in an important way to the merger of evidentiary practices by giving a stage to reexamine the strengths and weaknesses of different procedural and evidentiary mechanisms ${ }^{21}$.

Therefore, regardless of the legal system prevailing in a given state, in the light of evidentiary rules gradually approaching one another, and acknowledging that adversarial and inquisitorial systems reflect two distinct yet equally valid approaches toward the search for the truth, we may now turn to as fundamental a question as what may limit the truth-seeking process. Accordingly, when limitations on fact-finding are considered, the discussion may be narrowed down to one significant

18 CZERNIAK Dominika. Collection of location data in criminal proceedings -European (the EU and Strasbourg) standards.

19 KRZAN Bartłomiej. Admissibility of evidence and international criminal justice.

20 See for example AMBOS Kai. International Criminal Procedure: "Adversarial", "Inquisitorial” or "Mixed"? International Criminal Law Review, vol. 3, pp. 1-37, 2003; KEEN Peter Carmichael. Tempered Adversariality: The Judicial Role and Trial Theory in the International Criminal Tribunals. Leiden Journal of International Law, vol. 17, pp. 767-814, 2004 and MUNDIS Daryl A., From 'Common Law' Towards 'Civil Law': The Evolution of the ICTY Rules of Procedure and Evidence, Leiden Journal of International Law, vol. 14, pp. 367-382, 2001.

21 See JACKSON John, ROBERTS Paul. Beyond Common Law Evidence: Reimagining and Reinvigorating, Evidence Law as Forensic Science, op.cit., p. 815 and literature quoted there, in particular the analysis of a normative integration of criminal procedure described as a "hybridization" by DELMAS_ MARTY Mireille. Reflections on the "Hybridisation" of Criminal Procedure. In: JACKSON John, LANGER Máximo, TILLERS Peter (eds.). Crime, Procedure and Evidence in a Comparative and International Context. Essays in honour of Professor Mirjan Damaška, Oxford and Portland: Hart Publishing, 2008, pp. 251-260. 
problem - what evidence should be admissible as a basis of a criminal judgment? Generally, all evidence that is relevant and reliable should be preliminarily considered as admissible in criminal proceedings. Therefore, the rules on the admissibility of evidence may be perceived as always serving an aim to protect certain values that are challenged against the truth. This will be further explored in this volume by Giulio Ubertis ${ }^{22}$ and Paolo Ferrua ${ }^{23}$.

Three important and timely factors causing serious implications for fact-finding at trial can be identified. The first one relates to the pressing need for the efficient processing of criminal cases. Although that phenomenon is more often discussed from the perspective of shortcomings that adversely affect procedural fairness, the evidentiary issues seem to be equally important. The second concerns the long-discussed human rights perspective that must be taken into account when the evidence obtained against such rights is considered to be admitted at trial. This in particular applies to the rights of the defendant, such as the right to remain silent or the right to examine or have examined witnesses, and is essential if the standard of the due process (fair trial) is to be met. Finally, the digital revolution also has an impact on criminal evidence and has started to play a particularly important role in the discussion on the admissibility of evidence. These challenges will now be discussed in turn.

\section{The Admissibility of Evidence and Out-of-Trial Case Disposal}

The most recent and crucial factors limiting the pursuit of truth relate to the necessity to guarantee the efficiency of criminal proceedings. Virtually all countries are faced with this challenge, due to the enormous overload of criminal cases ${ }^{24}$. Broadly accepted

\footnotetext{
22 UBERTIS Giulio - I criteri di ammissibilita probatoria.

23 FERRUA Paolo - Ammissibilità della prova e divieti probatori

24 See comparatively on ways in which states try to ensure the efficiency of criminal proceedings in JEHLE Jörg-Martin, WADE Marianne. Coping with Overloaded Criminal Justice Systems. The Rise of Prosecutorial Power in Europe, Berlin: Springer 2006 and more recently the analysis covering
} 
negotiated agreements based on plea bargaining or other instruments made available to prosecutors allowing for disposition of cases outside of trial inevitably lead to ambiguous determination of the factual basis of decisions concerning the criminal liability of the defendant. While the judgment frequently relies on the evidence already considered as admissible by the prosecutor, the court's responsibility for admitting the evidence becomes limited. This changes the dynamics between the actors of criminal process and reinforces the position of the prosecutor, weakening the judicial influence on the outcome of criminal proceedings ${ }^{25}$. In theory, this may seem uncontroversial, since the negotiated procedures assume that the accused when pleading guilty adheres to evidence on which the prosecutor relies to proves defendant's guilt. However, when attention is paid to the details the question of authority playing a major role in the decision-making process regarding admissibility of evidence becomes more complicated. Such issues as the access of the defendant to evidence gathered during the investigation by criminal justice agencies and the exclusion of such evidence if necessary seems to be crucial in providing the defendant with the desired fairness of proceedings. Moreover, the advantages of various procedures allowing a full trial to be avoided may play an important role for the prosecutors and judges. Their ability to drastically reduce the caseload and smoothly close cases may negatively affect the willingness to question the facts established by the investigating authorities and accepted through the guilty plea. That may be the case even if there are potential lacunas in the case materials that would most probably have been raised and debated during trial. Certainly, the law may offer safeguards assuring that when the facts are disputed the case should be decided during an adversarial trial. Moreover, the fairness of proceedings may be guaranteed by demanding that the guilty plea be informed and voluntary. Nonetheless, the effectiveness of such provisions may be questioned when a defendant pleads guilty on

impressive variety of countries by LANGER Máximo. Plea-bargaining, Conviction Without Trial and the Global Administratization of Criminal Convictions, Annual Review of Criminology, 2021, vol. 4, pp. 377-411.

See on the redefinition of the position of the prosecutor during criminal process in: KREMENS Karolina. Powers of the Prosecutor in Criminal Investigation. A Comparative Perspective. New York: Routledge, 2021 (forthcoming). 
the basis of case materials containing evidence that should be excluded. An important role in that regard may be played by the defense counsel raising doubts toward the legality of obtained evidence. In this volume Thomas Weigend will seek an answer to these questions, arguing that rules on the exclusion of evidence should accordingly apply at an early stage of the criminal process ${ }^{26}$.

The avoidance of full trial raises doubts related to human rights issues. Convictions not preceded by full adversarial trial and based on limited evidence gathered in an inquisitorial manner by the investigating authorities, even if accepted by the defendant, are problematic. As a consequence, they may affect the integrity of criminal process, understood as a tool designed to do justice in the society. Similar dilemmas regarding the integrity of criminal process arise when not the quantity and reliability of evidence to support the conviction, as in the case of simplified procedures, but the legality or propriety of their acquisition is controversial. Today, it can no longer be convincingly claimed that "It matters not how you get it; if you steal it even, it would be admissible in evidence." ${ }^{27}$ If the allegations that the evidence were obtained improperly are raised they have to be addressed at trial.

\section{The Admissibility of Evidence and Improperly Obtained EVIDENCE}

As indicated, the goal of establishing the truth is not absolute and the criminal process does not function in a vacuum. Those who are suspects, defendants, victims or witnesses are also involved in a multitude of personal and professional relations that entail certain rights and duties. The rules of criminal procedure cannot be construed and applied without acknowledging that basic fact. In consequence, various values external to criminal process influence their shape and functioning. Some of them, like human dignity, acknowledged as a fundamental and

\footnotetext{
26 WEIGEND Thomas. Exclusion without trial? Exclusion of evidence and abbreviated procedures.

27 Per Crompton J in R. v. Leatham (1861) 8 Cox CC 498 at 501.
} 
universal principle ${ }^{28}$, have influenced the fact-finding process in the criminal context for at least a few centuries. The prohibition of torture and the privilege against self-incrimination, as basic principles safeguarding human dignity, are perhaps the best examples limiting the powers of investigating authorities ${ }^{29}$.

The last centuries, however, are marked with an even more visible tendency to limit the investigative powers of criminal justice agencies involved in the fact-finding process. Establishment of the exclusionary rule in the USA and its development prove that the observance of human rights (guaranteed in the Fourth, Fifth and Sixth Amendments) became a crucial factor limiting the pursuit of truth in criminal proceedings. Certainly, this tendency is not exclusive to the USA, although it is true that in that system the exclusion of evidence has been developed in the broadest way. Similar developments can also be observed in other countries $^{30}$. In this volume Frank Verbruggen and Charlotte Conings with regard to Belgian law $^{31}$ and Pasquale Bronzo and Guido Colaiacovo concerning the Italian system ${ }^{32}$ analyze national approaches toward the exclusion of illegally obtained evidence.

Apart from changes in domestic legal systems, the European standard regarding the exclusion of evidence obtained in violation of the European Convention on Human Rights (ECHR) ${ }^{33}$ was also developed

28 Article 1 of the Universal Declaration of Human Rights provides that all human beings are born free and equal in dignity and rights.

29 In the common law tradition, the origins of the privilege against self-incrimination are traced back as early as 1568 (CHOO Andrew L-T. The Privilege Against Self-Incrimination and Criminal Justice. Oxford-Portland: Oxford University Press, 2013, p. 2). On the prohibition of torture as a well-established principle in English common law see: A v Secretary of State for the Home Department (No 2) [2005] UKHL 71.

30 See for example THAMAN Stephen (ed.) Exclusionary Rules in Comparative Law, op.cit., Springer: Dordrecht-Heidelberg-New York-London 2013.

31 VERBRUGGEN Frank, CONINGS Charlotte. After Zigzagging Between Extremes, Finally Common Sense? Will Belgium Return to Reasonable Rules on Illegally Obtained Evidence?

32 BRONZO Pasquale, COLAIACOVO Guido. Delitto di tortura e inutilizzabilità delle prove nel sistema processuale italiano.

33 The Convention for the Protection of Human Rights and Fundamental Freedoms, opened for signature in Rome on 4 November 1950, came into force in 1953. 
in the case law of the European Court of Human Rights (ECtHR). And even though the Strasbourg Court is generally reluctant to intervene in the evaluation of evidence before national courts ${ }^{34}$, it nonetheless recognizes the relation between safeguarding rights of the parties to the proceedings and excluding improperly obtained evidence. Moreover, the judges perceive that relation in certain areas as strong enough to establish absolute exclusionary rules. For example, the ECtHR held that the admission of statements obtained as a result of torture or inhuman or degrading treatment, real evidence obtained directly by torture, as well as evidence obtained by police incitement renders the trial unfair in terms of Article $6 \mathrm{ECHR}^{35}$. More recently the scope of the exclusionary rule has been extended to cover statements admitted at trial obtained by torture administered by private individuals ${ }^{36}$, which will be further explored in this volume by Małgorzata Wąsek-Wiaderek 37. The ECtHR also developed a more nuanced approach to exclude evidence gathered in violation of the right to privacy ${ }^{38}$, the right to access to a lawyer ${ }^{39}$ as well as real (non-testimonial) evidence obtained by inhuman or degrading treatment ${ }^{40}$ and fruit of the poisonous tree of violations of inhuman or degrading treatment prohibition ${ }^{41}$. It is adopted that in such contexts, the exclusionary rule is not working automatically. The admission of evidence should therefore be assessed taking into consideration the totality of circumstances of the case and that the holistic approach determines the evaluation of the fairness of the proceedings.

Not surprisingly, the exclusion of evidence obtained in violation of human rights raises numerous controversies. The first

34 Cf. for example Jalloh v. Germany [GC], no. 54810/00, 11 July 2006, § 95.

35 Gäfgen v. Germany [GC], no. 22978/05, 1 June 2010, § 166-167.

36 Ćwik v. Poland, no. 31454/10, 5 November 2020.

37 WĄSEK-WIADEREK Małgorzata. Admissibility of Statements Obtained as a Result of "Private Torture" or "Private" Inhuman Treatment as Evidence in Criminal Proceedings: Emergence of a New European Standard?

38 Bykov v. Russia [GC], no. 4378/02, 10 March 2009.

39 Beuze v. Belgium [GC], no. 71409/10, 9 November 2018.

40 Jalloh v. Germany [GC], no. 54810/00, 11 July 2006.

41 Gäfgen v. Germany [GC], no. 22978/05, 1 June 2010. 
concerns whether the respect for human rights (the so-called protective principle ${ }^{42}$ ) is in fact a convincing rationale for the exclusion. Although the intuitive answer might seem positive, the existence of alternative justifications such as deterrence and integrity principles ${ }^{43}$ proves that human rights do not act as trump in deciding on the admissibility of evidence. Moreover, the historical development of the exclusionary rule in the USA indicates that the original justification for the exclusion of evidence obtained in violation of the Fourth Amendment, namely protection of rights of the individual, was replaced by understanding the exclusionary rule as an instrumental device designed to deter police misconduct ${ }^{44}$. Even though the rationale based on human rights protection is questioned and sometimes abandoned in favor of other rationale, the deterrence principle and integrity principle implicitly accept the argument that respect for rights of the individual should at least to some extent be taken under consideration while gathering evidence to establish the truth in criminal proceedings. Recourse to the moral integrity of the criminal justice system, which is based on the fundamental right to a fair trial, as well as to the principle of deterrence, which aims at safeguarding the dignity and liberty of individuals and protecting the rule of law, implicitly confirms that while gathering evidence the rights of people subjected to investigative actions cannot be ignored.

42 Term used in ASHWORTH Andrew. Excluding Evidence as Protecting Rights. Criminal Law Review, vol. 3, pp. 723-735, 1977.

${ }^{43}$ See for example CHAU Peter. Excluding Integrity? Revisiting Non-Consequentialist Justifications for Excluding Improperly Obtained Evidence in Criminal Trials. In: ROBERTS Paul, HUNTER Jill, YOUNG Simon NM., DIXON David (eds.). The Integrity of Criminal Process. From Theory into Practice, Oxford-Portland: Hart Publishing, 2016, p. 279, ASHWORTH Andrew. Exploring the integrity principle in evidence and procedure In: MIRFIELD Paul, SMITH Roger. Essays for Colin Tapper, Oxford-New York: Lexis-Nexis, 2003, pp. 107-125, TURNER Jenia Iontcheva, WEIGEND Thomas. The Purposes and Functions of Exclusionary Rules: A Comparative Overview In: GLESS Sabine, RICHTER Thomas (eds.). Do Exclusionary Rules Ensure a Fair Trial? A Comparative Perspective on Evidentiary Rules. Cham: Springer, 2019, pp. 255-263.

${ }^{44}$ MACLIN Tracey. The Supreme Court and Fourth Amendment's Exclusionary Rule. Oxford-New York: Oxford University Press, 2013, pp. 348-349. 
The emphasis makes, nonetheless, a substantive difference. While the protective principle is focused primarily on the rights of the individual, the other justifications imply a more complex weighing of competing interests. A good illustration of the latter are exceptions to the exclusionary rule created in case law. In a landmark judgment United States $v$. Leon ${ }^{45}$ establishing the "good faith" exception to the Fourth Amendment exclusionary rule, the US Supreme Court ruled that if the police officer executing a search warrant acted in good faith and within its scope, the evidence gathered should not be excluded even if the warrant ultimately was found to be invalid. As a result, narrowing the scope of the exclusionary rule proves that the violation of the individual's rights is not sufficient to suppress evidence. A similar approach can be observed in the case law of the ECtHR. In Al-Khawaja and Tahery vs. United Kingdom it was decided that the right to a fair trial is a complex concept encompassing, apart from the rights of the defense, also the interests of the public and the victims of crime as well as, where necessary, the rights of the witnesses ${ }^{46}$. Therefore, it should be no surprise that limitations to the exclusion of evidence based on human rights arguments started to proliferate among various jurisdictions after the initial protective approach ${ }^{47}$.

Moreover, the tension between safeguarding accurate fact-finding and imposing limitations on that process related to considerations of external values is clearly visible in different approaches to the exclusion of material (real) evidence and testimonial evidence. The ECtHR case law regarding real and testimonial evidence obtained in violation of Article 3 of the ECHR may serve as a good example. While the Strasbourg Court is firm in stating that admission at trial before the domestic court of

45468 U.S. 897 (1984).

46 Al-Khawaja and Tahery vs. United Kingdom, nos. 26766/05 and 22228/06, 23 May 2006, § 118.

47 In that context it is worth mentioning the example of Spain, where the exclusionary rule referring both to direct and indirect evidence (Article 11(1) Ley Orgánica 6/1985, de 1 de julio, del Poder Judicial) is interpreted by the judicial authorities as having exceptions in cases of fruit of the poisonous tree. See: BACHMAIER WINTER Lorena. Spain: The Constitutional Court's Move from Categorical Exclusion to Limited Balancing, op.cit., pp. 215-217. 
depositions obtained by torture and inhuman or degrading treatment violates the right to a fair trial, the same standard is not applied in respect of real evidence obtained by inhuman or degrading treatment ${ }^{48}$. Moreover, the ECtHR adopts a very inclusive attitude toward real evidence obtained by violation of the right to privacy ${ }^{49}$. Although it was not articulated explicitly by the Court, the reason for an adoption of the dual standard seems to be related to a distinct assessment of the reliability of material and testimonial evidence. The implicit emphasis on reliability of evidence as a crucial factor in deciding on its admissibility can be noticed in many jurisdictions in an inclusive approach to admitting real evidence obtained during a search conducted in violation of a right to privacy ${ }^{50}$. Naturally, it may be a matter of dispute how respect for human rights or the pursuit of truth should be weighed. However, even if the inclusive trend in admissibility decisions related to improperly obtained evidence is visible in many jurisdictions, no one advocates that violations of human rights should be disregarded. Rather they are treated as one of the factors that should be assessed, with an emphasis on the seriousness and intentionality of violation ${ }^{51}$. These arguments relating to the optimum scope of the exclusion of reliable evidence and limitation of search for the truth are becoming equally important in the context of the most challenging revolution concerning evidence law the era of digital evidence.

48 Jalloh v. Germany [GC], no. 54810/00, 11 July 2006.

49 See for example Bykov v. Russia, no. 4378/02, 10 March 2009 and the criticism of that approach in dissenting opinions.

50 It is visible in at least questionable distinction between legality of search itself and seizure of evidence revealed by search stemming from case law of German and Italian courts (THAMAN Stephen C. Balancing Truth Against Human Rights: A Theory of Modern Exclusionary Rules [w:] Exclusionary Rules in Comparative Law, In: THAMAN Stephen C. (ed.) Exclusionary Rules in Comparative Law, op.cit., p. 434; RUGGIERI Francesca; MARCOLINI Stefano. Italy. In: LIGETI Katalin (ed.). Toward a Prosecution for the European Union, Volume 1. A Comparative Analysis, Oxford-Portland: Hart Publishing, 2013, p. 396).

51 See WEIGEND Thomas. Germany. In: LIGETI Katalin (ed.). Toward a Prosecution for the European Union, Volume 1. A Comparative Analysis, op.cit., p. 296. 


\section{The Admissibility of Evidence and the Technological DeVelopments}

The expansion of new technologies experienced during the past forty years certainly has not left the criminal justice system untouched. Without exaggeration this process can be called one of the greatest challenges that the criminal law and procedure has been faced with. And yet it is uncertain how influential this process might be in the future, as the creation of new technologically advanced devices and tools is speeding up. The self-driving cars tested in cities, the development of the $5 \mathrm{G}$ network or the rising popularity of home assistants and smart TVs that were all unimaginable even a decade ago are just a few examples of a rapidly changing reality which does not leave the criminal law beyond its influence.

Certainly, it is not a novel reflection that the growth of the impact of science on our lives is also influencing the criminal law ${ }^{52}$. This process is constantly observed through such mechanisms as electronic monitoring of convicts ${ }^{53}$ and the significant increase in the digitalization of court proceedings that allows for the conducting of proceedings through highquality video link. It is no longer impossible to imagine court hearings happening online, as this takes place every day in many national and international courts and started long before the social distancing requirements of COVID-1954. It would be, therefore, surprising if the digital revolution did not influence the engagement of criminal evidence in the fact-finding process.

52 See very recently CAIANELLO Michele. Criminal Process faced with the Challenges of Scientific and Technological Development, European Journal of Crime, Criminal Law and Criminal Justice 2019, vol. 27, pp. 265-289.

53 See NELLIS Mike, The Electronic Monitoring of Offenders in England and Wales: Recent Developments and Future Prospects, The British Journal of Criminology, vol. 31 (2), 1991, pp. 165-185 and more recently NELLIS Mike, Understanding the Electronic Monitoring of Offenders in Europe: Expansion, Regulation and Prospects, Crime, Law and Social Change, vol. 62, 2014, pp. 489-510.

54 See one example of the pre-covid era in online hearings by MENASHE Doron, A Critical Analysis of the Online Court, University of Pennsylvania Journal of International Law, vol. 39 (4), 2018, pp. 921-953. 
Perhaps the earliest signs of it have been the use of scientific evidence and the expansion of forensic science leaving a significant mark on the evidentiary rules more than a hundred years ago. The discussion over the reliability of scientific evidence that swept through the US system ${ }^{55}$ are just one of many examples of how the rules on admissibility of evidence demand a distinct approach when scientific knowledge that is hard to grasp and control becomes a part of evidence-taking. This is definitely not yet a completed chapter and the cases of wrongful convictions based on pseudoscience or resulting from the lack of proper testing of biological samples are just the tip of the iceberg ${ }^{56}$. The wrongful convictions are also frequently caused by the improper identification. In this volume Janaina Matida and William Weber Cecconello discuss that issue in the context of identification by eyewitness through photographs ${ }^{57}$. Some other contemporary problems of exclusion of scientific expert evidence from the Continental perspective are also discussed in this volume by Juan Sebastian Vera Sanchez ${ }^{58}$.

However, the technological development has also already left its mark on the gathering of criminal evidence. For one, the police and other agencies have gained immediate access to various databases from the level of the police car which allows them to verify the identity of a stopped car or a person on the $\operatorname{spot}^{59}$. Quicker access to data has facilitated the

55 See the landmark cases Frye v. United States, 293 F. 1013 (D.C. Cir. 1923) and Daubert v. Merrell Dow Pharmaceuticals, Inc., 509 U.S. 579 (1993). See also critically on the Frye-Daubert standard by HILBERT Jim. The Disappointing History of Science in the Courtroom: Frye, Daubert, and the Ongoing Crisis of "Junk Science" in Criminal Trials. Oklahoma Law Review, vol. 71, 2019, pp. 759-821.

56 See also an interesting piece on the perceptible need for a change of the law of evidence in the common law system faced with the use of forensic science by JACKSON John; ROBERTS Paul. Beyond Common Law Evidence: Reimagining and Reinvigorating, Evidence Law as Forensic Science, op.cit., pp. 787-820.

57 MATIDA Janaina and CECCONELLO William Weber. Reconhecimento fotográfico e presunção de inocência.

58 VERA SANCHEZ Juan Sebastian. Exclusión de la prueba pericial científica (de baja calidad epistémica) en fase de admisibilidad en procesos penales de tradición románica-continental.

59 This is not limited to the most common databases such as for fugitives, suspected criminals, fingerprints, DNA profiling etc. See an analysis on the role 
actions of the police and led to more accurate verification of offenders or persons at large. Moreover, the drive toward recording daily activities of criminal justice agencies plays a crucial role in creating convincing evidence. Video recordings are available not only during interrogations conducted at the police station, but body-worn cameras are nowadays even placed onto officers' uniforms providing on-site coverage of their interactions with the public, which makes them a remarkable argument in the courtroom ${ }^{60}$. The most recent novelty in that regard is the use of artificial intelligence as a tool for providing criminal evidence ${ }^{61}$. The use of these new tools brings another risk to the traditional approach toward the administration of justice blurring the boundaries between preventive and traditionally repressive criminal justice ${ }^{62}$. This can be observed for example in the US federal system, which has already widely employed algorithmic risk assessment tools in criminal sentencing processes ${ }^{63}$.

Another example of challenges faced by criminal justice systems in the context of admissibility of evidence resulting directly from the development of new technologies is the issue of access obtained by

of genetic genealogy databases in discovery of a crime by GUERRINI Christi J.; ROBINSON Jill O.; PETERSEN Devan, McGUIRE Amy L. Should police have access to genetic genealogy databases? Capturing the Golden State Killer and other criminals using a controversial new forensic technique, PLOS Biology, 2 October 2018 https://doi.org/10.1371/journal.pbio.2006906.

${ }^{60}$ See SOUSA William H., COLDREN James R.; RODRIGUEZ Denise Jr., BRAGA Anthony A. Research on Body Worn Cameras: Meeting the Challenges of Police Operations, Program Implementation, and Randomized Controlled Trial Designs, Police Quarterly, vol. 19 (3), 2016, https://doi. org/10.1177/1098611116658595

${ }^{61}$ GLESS Sabine. AI in the Courtroom: A Comparative Analysis of Machine Evidence in Criminal Trials, Georgetown Journal of International Law vol. 51, 2020, pp. 195-253.

${ }^{62}$ CAIANELLO Michele. Criminal Process faced with the Challenges of Scientific and Technological Development. European Journal of Crime, Criminal Law and Criminal Justice, vol. 27, pp. 265-289, 2019, p. 279.

KEHL Danielle; GUO Priscilla; KESSLER Samuel. Algorithms in the Criminal Justice System: Assessing the Use of Risk Assessments in Sentencing. Responsive Communities Initiative, Berkman Klein Center for Internet \& Society, Harvard Law School, July 2017, https://dash.harvard.edu/bitstream/ handle/1/33746041/2017-07_responsivecommunities_2.pdf (accessed 25.01.2021). 
law enforcement agencies to data stored on electronic carriers, such as computers, cellphones, clouds, etc. This strongly interrelates to the discussion on exclusionary rules but sheds a new perspective on how the evidentiary rules should be drafted in this new context. The traditional rules on admissibility of evidence developed over centuries for the purpose of house searches and personal searches did not foresee the problems that come with the complexity of electronic devices storing gigabytes of highly personal data ${ }^{64}$.

One striking illustration of that problem is the admissibility of evidence obtained from cellphones. Cellphones differ distinctly from any other object that may be found on a person. They are constantly accessible, portable, and may be used for multiple purposes, giving a space for social and emotional communication ${ }^{65}$. They are even considered such a pervasive and insistent part of daily life that, as one judge has stated, "the visitor from Mars might conclude they were an important feature of human anatomy." ${ }^{66}$ Most importantly, modern smartphones contain highly private data that can only be compared to what is kept at home and certainly not to what is found in someone's pocket or wallet.

Therefore, the key issue in this discussion concerns the limits of interference of criminal justice authorities with data contained on smartphones and whether the police should have similar powers to search such devices as they usually have for searching a person and their belongings at the time of arrest. So far this has been answered ambiguously both on a normative level ${ }^{67}$ as well as in the case law ${ }^{68}$.

64 SACHAROFF Laurent. The Fourth Amendment Inventory as a Check on Digital Searches, Iowa Law Review vol. 105, pp. 1643-1699, 2020, p. 1645.

65 FOWLER Joanna E.N.; Noyes Janet M. From dialing to tapping: University students report on mobile phone use. Procedia Manufacturing, vol. 3, pp. 4716-4723, 2015, p. 4717.

66 Riley v. California, 573 U.S. 373 (2014), at 2484.

67 The attempts to regulate the issue of cellphone searches provide a variety of resolutions and there is no common ground achieved. See for example the Formobile project devoted to analysis on how the current criminal procedure laws in the EU Member States deal with the topic of mobile forensics https:// www.timelex.eu/en/horizon-projects/formobile (accessed 21.01.2021).

68 See for example Hoge Raad Judgment of 4 April 2017, ECLI:NL:HR:2017:584 available at https://uitspraken.rechtspraak.nl/inziendocument?id=ECLI:NL: 
Particularly interesting in that regard has been the dialogue that took place in 2014 among North American courts taking different stances on that issue. One position was adopted by the US Supreme Court in a split judgment Riley v. California ${ }^{69}$. In a majority opinion the Court confirmed the uniqueness of the cellphone as an object and established that because of that feature the cellphone cannot be searched based on the same grounds as in the case of other objects found on a person ${ }^{70}$. The decision has clearly favored privacy interests with respect to all data contained in portable devices and recognized these interests as more valuable than the effectiveness of criminal investigation. The judgment has made the lives of criminal justice authorities just a bit harder by forcing them to obtain judicial search warrants prior to engaging in searching practices. Interestingly, almost at the same time the issue of cellphone searches was deliberated by the Canadian Supreme Court in $R v$. Fearon ${ }^{71}$. In the split decision the Court came up with exactly the reverse opinion, arguing that the cellphone search falls under the same old common law rule of searches incident to arrest without a warrant. The Court just added some additional safeguards as the cellphone search potentially brings a more significant invasion of privacy than the other similar searches. The additional protection proposed by the court, focused on such technicalities

HR:2017:584. (The Dutch court has presented the view that that if the search concerned a small amount of certain data stored or available on the electronic data carrier such as cellphone it may be that the search is justified. On the other hand, if the search is so far-reaching that a more or less complete picture is obtained of certain aspects of the personal life of the user of the data carrier or the computerized work, this investigation may be considered as unlawful.) See also a short note on the case in English https://www.liberties.eu/en/stories/ dutch-police-can-search-smartphone/11769. Riley v. California, 573 U.S. 373 (2014).

See comments on this judgment by George DERY III M., MEEHAN Kevin. A New Digital Divide? Considering the Implications of Riley v. California's Warrant Mandate for Cell Phone Searches. University of Pennsylvania Journal of Law and Social Change vol. 18 (4), 2015, pp. 311-339 and comparing it with the Italian standard by LASAGNI Giulia, Tackling phone searches in Italy and the United States: Proposals for a technological rethinking of procedural rights and freedoms, New Journal of European Criminal Law, vol. 9 (3), 2018, pp. 386-401.

71 R v. Fearon 2014 SCC 77. 
as the taking of notes by the police officers while conducting the search, has been criticized both in concurring opinion and in literature ${ }^{72}$.

The concurring perspectives delivered in these judgments, which split even internally, prove that the case of the legality of cellphone searches demands more careful attention, as weighing the value of privacy interests against the law enforcement objectives in the digital era is all but self-evident. This seems to be extending analogically to other cases of technological developments touching on the sphere of evidencetaking which through their novelty create multidimensional challenges to the criminal justice system. One thing however appears to be beyond question: these challenges call for immediate regulation as those who commit crimes make use of new devices and digital technology without any restraints. The states cannot be reluctant in providing legislation regulating such issues and wait for the courts to resolve the problems on a case-by-case basis. But how a balance is struck between the needs of society in successfully investigating crimes in a way that responds to criminals' use of technology without violating the rights of an individual is the question that should be quickly answered. And this most likely cannot be answered in isolation by a single state, as the ease with which digital evidence crosses borders demands unified and collective action.

\section{Conclusions}

It is undisputed that relevant and reliable evidence should generally be admissible in criminal proceedings. Their admissibility secures accurate fact-finding as a prerequisite for the correct application of substantive criminal law and, as a consequence, proper operation of the criminal justice system in society. At the same time the search for the truth must be limited in order to take into account other important values, among which human rights hold a central place. A matter of dispute is however how the competing interests should be balanced. That results in significant differences in views on the optimum shape of provisions related to admissibility of evidence.

72 See comments on this judgment by SKOLNIK Terry. Improving the Current Law of Warrantless Cellphone Searches after R v. Fearon, Revue Juridique Thémis de l'Université de Montréal, vol. 49, 2015, pp. 825-833. 
That divergence is understandable taking into consideration the competing approaches as well as the desired way of verifying admissibility of evidence. The latter, relating to the choice between a trial before professional judges or a jury, is of vital importance. Even though the identified variances are remarkable, the noticeable convergence trends may be identified as well. The drive toward effective international cooperation in criminal matters and the need for the universal protection of human rights are the main reasons forcing the approximation of provisions related to the admissibility of evidence. It seems the traditionally recognized distinction between the common law and civil law models is becoming less important in light of the progressive integration of systems. Certainly, that process is not linear and we should not expect that a common unified standard emerges soon. Yet, its influence on national laws of evidence should not be marginalized, of which the EU cooperation in criminal matters is just one of the most remarkable examples.

The admissibility of evidence, apart from being subjected to divergent and convergent trends, also faces other important challenges. The first of them is the need for the protection of human rights. As in previous decades, the quest for a fair balance between the effective fight against crime and respect for individual rights will be in the center of heated discussion. However, there are two other factors that strongly influence the evidentiary rules, creating an environment where finding the truth becomes more complicated than ever before. The popularity of the disposition of cases out of trial and the impact of technology and science, both interrelated and focused on the efficiency of the criminal justice system, paradoxically make the quest for the truth easier and faster, but at the same time more prone to errors. Moreover, the new technologies allowing evidence gathering have become a vital threat to the right to privacy.

Certainly, there is hope in what we experience. As Caianiello predicts, "the traditional bases of fact-finding at trial can endure even against these [scientific and technological] challenges." ${ }^{73}$ He adds that it is possible only as far as lawyers and scholars will be able to approach the new available tools with a sufficient amount of criticism. This seems

73 CAIANIELLO Michele. Criminal Process faced with the Challenges of Scientific and Technological Development. op.cit., p. 265. 
to be crucial to face the challenges. None of them can be answered in a simple and universal way. Finding solutions necessitates dialogue including various stakeholders and free of the penal populism that has dominated the legal discourse in at least several countries. An important part of that discussion should be devoted to comparative analysis, which allows countries to share and profit from the experience of other legal systems. This issue of Revista Brasileira de Direito Processual Penal aims at achieving that goal. And while closing this brief discussion let us give a floor to those who will provide an answer to some of the questions raised toward the modern challenges of admissibility of evidence in criminal procedure.

\section{BiBLIOGRAPHY}

AMBOS Kai. International Criminal Procedure: "Adversarial”, "Inquisitorial” or "Mixed"? International Criminal Law Review, vol. 3, pp. 1-37, 2003. https://doi. org/10.1163/156753603767877084

ASHWORTH Andrew. Excluding Evidence as Protecting Rights. Criminal Law Review, vol. 3, pp. 723-735, 1977.

ASHWORTH Andrew. Exploring the integrity principle in evidence and procedure En: MIRFIELD Paul, SMITH Roger. Essays for Colin Tapper, Oxford-New York: Lexis-Nexis, 2003.

ASHWORTH Andrew; REDMAYNE Mike. The Criminal Process. Oxford: Oxford University Press, 2010.

BACHMAIER WINTER Lorena. Spain: The Constitutional Court's Move from Categorical Exclusion to Limited Balancing. En: THAMAN Stephen C. (ed.) Exclusionary Rules in Comparative Law. Springer: Dordrecht-Heidelberg-New York-London, 2013. https://doi.org/10.1007/978-94-007-5348-8_9

BORGERS Matthias J.; STEVENS Lonneke. The Netherlands: Statutory Balancing and a Choice of Remedies. En: THAMAN Stephen C. (ed.) Exclusionary Rules in Comparative Law. Springer: Dordrecht-Heidelberg-New York-London, 2013. https://doi.org/10.1007/978-94-007-5348-8_8

BRADLEY Craig M.; HOFFMNN Joseph L. Public Perception, Justice and the "Search for the Truth" in Criminal Cases. Southern California Law Review, vol. 69, pp. 1267-1302, 1996.

CAIANELLO Michele. Criminal Process faced with the Challenges of Scientific and Technological Development, European Journal of Crime, Criminal Law and Criminal Justice 2019, vol. 27. https://doi.org/10.1163/15718174-02704001 
CAIANELLO Michele. Criminal Process faced with the Challenges of Scientific and Technological Development. European Journal of Crime, Criminal Law and Criminal Justice, vol. 27, pp. 265-289, 2019. https://doi.org/10.1163/15718174-02704001

CHAU Peter. Excluding Integrity? Revisiting Non-Consequentialist Justifications for Excluding Improperly Obtained Evidence in Criminal Trials. En: ROBERTS Paul, HUNTER Jill, YOUNG Simon NM., DIXON David (eds.). The Integrity of Criminal Process. From Theory into Practice, Oxford-Portland: Hart Publishing, 2016. https://doi.org/10.5040/9781474201407.ch-011

CHOO Andrew L-T. The Privilege Against Self-Incrimination and Criminal Justice. Oxford-Portland: Oxford University Press, 2013.

DAMAŠKA Mirjan. The jury and the law of evidence: real and imagined interconnections. Law, Probability and Risk, vol. 5, issue 3-4, pp. 255-265, 2006. https:// doi.org/10.1093/lpr/mgm009

DELMAS_MARTY Mireille. Reflections on the "Hybridisation" of Criminal Procedure. En: JACKSON John, LANGER Máximo, TILLERS Peter (eds.). Crime, Procedure and Evidence in a Comparative and International Context. Essays in honour of Professor Mirjan Damaška, Oxford and Portland: Hart Publishing, 2008. https://doi.org/10.5040/9781472564528.ch-013

FOWLER Joanna E.N.; Noyes Janet M. From dialing to tapping: University students report on mobile phone use. Procedia Manufacturing, vol. 3, pp. 4716-4723, 2015. https://doi.org/10.1016/j.promfg.2015.07.568

George DERY III M., MEEHAN Kevin. A New Digital Divide? Considering the Implications of Riley v. California's Warrant Mandate for Cell Phone Searches. University of Pennsylvania Journal of Law and Social Change vol. 18 (4), 2015.

GLESS Sabine. AI in the Courtroom: A Comparative Analysis of Machine Evidence in Criminal Trials, Georgetown Journal of International Law vol. 51, 2020.

GUERRINI Christi J.; ROBINSON Jill O.; PETERSEN Devan, McGUIRE Amy L. Should police have access to genetic genealogy databases? Capturing the Golden State Killer and other criminals using a controversial new forensic technique, PLOS Biology, 2 October 2018. https://doi.org/10.1371/journal.pbio.2006906

HILBERT Jim. The Disappointing History of Science in the Courtroom: Frye, Daubert, and the Ongoing Crisis of "Junk Science" in Criminal Trials. Oklahoma Law Review, vol. 71, 2019.

HO Hock Lai. A Philosophy of Evidence Law. Justice in the Search for Truth, Oxford: Oxford University Press, 2010.

HODGSON Jacqueline S. The Metamorphosis of Criminal Justice. A Comparative Account, Oxford: Oxford University Press, 2020. 
JACKSON John; ROBERTS Paul. Beyond Common Law Evidence: Reimagining and Reinvigorating, Evidence Law as Forensic Science. En: BROWN Darryl K., TURNER Jenia J.; WEISSER Bettina (eds.). The Oxford Handbook of Criminal Process, Oxford: Oxford University Press, 2019. https://doi.org/10.1093/ oxfordhb/9780190659837.013.40

JEHLE Jörg-Martin, WADE Marianne. Coping with Overloaded Criminal Justice Systems. The Rise of Prosecutorial Power in Europe, Berlin: Springer 2006.

KEEN Peter Carmichael. Tempered Adversariality: The Judicial Role and Trial Theory in the International Criminal Tribunals. Leiden Journal of International Law, vol. 17, pp. 767-814, 2004. https://doi.org/10.1017/s0922156504002225

KEHL Danielle; GUO Priscilla; KESSLER Samuel. Algorithms in the Criminal Justice System: Assessing the Use of Risk Assessments in Sentencing. Responsive Communities Initiative, Berkman Klein Center for Internet \& Society, Harvard Law School, July 2017.

KREMENS Karolina. Dowody osobowe w międzynarodowym postępowaniu karnym. Toruń: TNOiK, 2010.

KREMENS Karolina. Powers of the Prosecutor in Criminal Investigation. A Comparative Perspective. New York: Routledge, 2021 (forthcoming).

KUSAK Martyna, Mutual admissibility of evidence in criminal matters in the EU. A study of telephone tapping and house search, Antwerpen: Maklu, 2016.

LANGER Máximo. Plea-bargaining, Conviction Without Trial and the Global Administratization of Criminal Convictions, Annual Review of Criminology, 2021, vol. 4. https://doi.org/10.1146/annurev-criminol-032317-092255

LASAGNI Giulia, Tackling phone searches in Italy and the United States: Proposals for a technological rethinking of procedural rights and freedoms, New Journal of European Criminal Law, vol. 9 (3), 2018. https://doi.org/10.1177/2032284418798053 MACLIN Tracey. The Supreme Court and Fourth Amendment's Exclusionary Rule. Oxford-New York: Oxford University Press, 2013. https://doi.org/10.1093/ acprof:oso/9780199795475.001.0001

MENASHE Doron, A Critical Analysis of the Online Court, University of Pennsylvania Journal of International Law, vol. 39 (4), 2018.

MITSILEGAS Valsamis. EU Criminal Law. Oxford: Oxford and Portland: Hart Publishing, 2009.

MUNDIS Daryl A., From 'Common Law' Towards 'Civil Law': The Evolution of the ICTY Rules of Procedure and Evidence, Leiden Journal of International Law, vol. 14, pp. 367-382, 2001. https://doi.org/10.1017/s0922156501000188 
NELLIS Mike, The Electronic Monitoring of Offenders in England and Wales: Recent Developments and Future Prospects, The British Journal of Criminology, vol. 31 (2), 1991.

NELLIS Mike, Understanding the Electronic Monitoring of Offenders in Europe: Expansion, Regulation and Prospects, Crime, Law and Social Change, vol. 62, 2014. https://doi.org/10.1007/s10611-014-9540-8

ROBERTS Paul; ZUCKERMAN Adrian, Criminal Evidence, Oxford: Oxford University Press, 2010.

RUGGIERI Francesca; MARCOLINI Stefano. Italy. En: LIGETI Katalin (ed.). Toward a Prosecution for the European Union, Volume 1. A Comparative Analysis, Oxford-Portland: Hart Publishing, 2013.

RYAN Andrea. Towards a System of European Criminal Justice. The Problem of Admissibility of Evidence, New York: Routledge 2014. https://doi. org/10.4324/9781315770031

SACHAROFF Laurent. The Fourth Amendment Inventory as a Check on Digital Searches, Iowa Law Review vol. 105, pp. 1643-1699, 2020.

SKOLNIK Terry. Improving the Current Law of Warrantless Cellphone Searches after R v. Fearon, Revue Juridique Thémis de l'Université de Montréal, vol. 49, 2015.

SOUSA William H., COLDREN James R.; RODRIGUEZ Denise Jr., BRAGA Anthony A. Research on Body Worn Cameras: Meeting the Challenges of Police Operations, Program Implementation, and Randomized Controlled Trial Designs, Police Quarterly, vol. 19 (3), 2016. https://doi.org/10.1177/1098611116658595

SPENCER John R. Evidence. En: DELMAS-MARTY Mireille; SPENCER John R. European Criminal Procedures, Cambridge: Cambridge University Press, 2002.

TURNER Jenia Iontcheva, WEIGEND Thomas. The Purposes and Functions of Exclusionary Rules: A Comparative Overview. In: GLESS Sabine, RICHTER Thomas (eds.). Do Exclusionary Rules Ensure a Fair Trial? A Comparative Perspective on Evidentiary Rules. Cham: Springer, 2019. https://doi. org/10.1007/978-3-030-12520-2_8

VANDERMEERSCH Damien, Droit continental vs. droit anglo-américain: quells enseignements pour le droit belge de la procédure pénale, Revue de Droit Penal et de Criminologie, 2001, pp. 467-531.

WALTOŚ Stanisław; HOFMAŃSKI Piotr. Proces karny. Warszawa: Wolters Kluwer, 2016. 
WEIGEND Thomas. Germany. En: LIGETI Katalin (ed.). Toward a Prosecution for the European Union, Volume 1. A Comparative Analysis, Oxford-Portland: Hart Publishing, 2013.

WEIGEND, Thomas. Should We Search for the Truth, and Who Should Do it? North Carolina Journal of International Law and Commercial Regulation, vol. XXXVI, pp. 389-415, 2011.

\section{Informações adicionais e declarações do autor (integridade científica)}

Acknowledgment: This publication has been developed as part of the project Admissibility of Evidence in Criminal Proceedings. Between Truth Seeking, Fairness and Effectiveness of Proceedings (Registration No. 2017/27/B/HS5/00854) financed by the National Science Centre, Poland.

Conflict of interest declaration: the authors confirm that there are no conflicts of interest in conducting this research and writing this article.

Declaration of authorship: all and only researchers who comply the authorship requirements of this article are listed as authors; all coauthors are fully responsible for this work in its entirety.

- Karolina Kremens: conceptualization, methodology, data curation, investigation, writing - original draft, validation, writing - review and editing, final version approval.

- Wojciech Jasiński: methodology, data curation, investigation, writing - original draft, validation, writing - review and editing, final version approval.

Declaration of originality: the authors assure that the text here published has not been previously published in any other resource and that future republication will only take place with the express indication of the reference of this original publication; they also attest that there is no third party plagiarism or self-plagiarism. 


\section{COMO CITAR ESTE EDITORIAL:}

KREMENS, Karolina; JASIŃSKI, Wojciech. Editorial of dossier "Admissibility of Evidence in Criminal Process. Between the Establishment of the Truth, Human Rights and the Efficiency of Proceedings". Revista Brasileira de Direito Processual Penal, Porto Alegre, vol. 7, n. 1, p. 15-42, jan./abr. 2021. https://doi.org/10.22197/rbdpp.v7i1.537

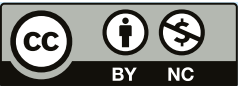

Esta obra está licenciada com uma Licença Creative Commons Atribuição-NãoComercial 4.0 Internacional. 